\title{
Alternans in human atrial monophasic action potential
}

\author{
T. POP AND D. FLEISCHMANN
}

From First Medical Division, Rheinisch-Westfälische Technische Hochschule, Aachen, West Germany

This report describes the case of a patient with a supraventricular tachycardia with a ventricular rate of $109 /$ min and no visible $P$ waves in the electrocardiogram. The recording of the monophasic action potential of the right atrium disclosed an atrial tachycardia with a rate of 218/min. There was an alternans of the phase 2 of repolarisation in the action potential. This report emphasises the fact that the phenomenon of alternans occurs in man, as in the experimental animal, at a cellular level.

Electrical alternation of the ventricular complexes in man was first reported by Lewis (1910). Reviews of further cases have been made by Hamburger et al. (1935), Spang (1957), Colvin (1958), Schamroth et al. (1959), Chung et al. (1964), and Bellet (1971). Alternation of the $P$ waves has been described by Bernreiter (1956), Kisch (1949), and Piso (1956). To the best of our knowledge, alternation of the human atrial monophasic action potential has not been yet documented. Recently, we observed this phenomenon in one of our patients.

\section{Case report}

A 65-year-old man was admitted because of severe congestive heart failure. There was an earlier history of anterolateral myocardial infarction in 1965. During 1965 he also developed atrial fibrillation and was subsequently treated with digoxin $0.4 \mathrm{mg}$ daily. Physical examination revealed signs of congestive heart failure. A grade 4/6 holosystolic murmur was present at the apex radiating to the axilla. The heart rhythm was regular, with a rate of $109 / \mathrm{min}$. The blood pressure was $130 / 80 \mathrm{mmHg}$. There were moist râles at both bases. The liver was enlarged three finger breadths below the right costal margin.

Laboratory tests showed blood urea $14.9 \mathrm{mmol} / 1$ $(89 \mathrm{mg} / 100 \mathrm{ml})$, creatinine $132.6 \mu \mathrm{mol} / 1(1.5 \mathrm{mg} /$ $100 \mathrm{ml}$ ), and digoxin $4.6 \mathrm{nmol} / 1(3.6 \mathrm{ng} / \mathrm{ml})$. The other tests were within normal limits.

The electrocardiogram (Fig. 1) showed a regular supraventricular rhythm with no visible $P$ waves. There were also significant $Q$ waves in leads $I$, aVL, V5, and V6, compatible with an old anterolateral myocardial infarction.

In order to identify the atrial deflections, the right atrial monophasic action potential was recorded (Olsson et al., 1971; Pop et al., 1976). At this stage an atrial rate of $218 / \mathrm{min}$, twice the ventricular rate $(109 / \mathrm{min}$ ), was seen (Fig. 2). The atrial deflections showed an alternans of the rate of repolarisation so that the duration of the monophasic action potential at 90 per cent of repolarisation alternately measured 170 and $210 \mathrm{~ms}$, respectively.

In spite of intensive therapy, the patient's state deteriorated progressively and death occurred 3 days after admission. On the day before death, the patient again experienced atrial fibrillation.

\section{Discussion}

The patient had had persistent atrial fibrillation since 1965. Before admission he developed regular atrial tachycardia with a rate of $218 / \mathrm{min}$ and a $2: 1 \mathrm{AV}$ block associated with raised serum digoxin concentration. Thus the diagnosis of a digitalis-induced atrial tachycardia with block is easily made (Levine, 1966).

The monophasic action potential has a configuration similar to that of an action potential recorded in its immediate vicinity (Hoffman et al., 1959). For this reason, the same notations are used for the depolarisation and for the repolarisation phases. Fig. 2 shows action potentials with distinct phase 2 of repolarisation. Such action potentials characterise the atrial specialised cells which have the potential to develop pacemaker activity (Hoffman and Cranefield, 1960; Hogan and Davis, 1968). The enhanced automaticity of such cells induced by digitalis presumably represents the electrophysiological basis of atrial tachycardia in our case (Hoffman and Singer, 1964). We assume that the group 


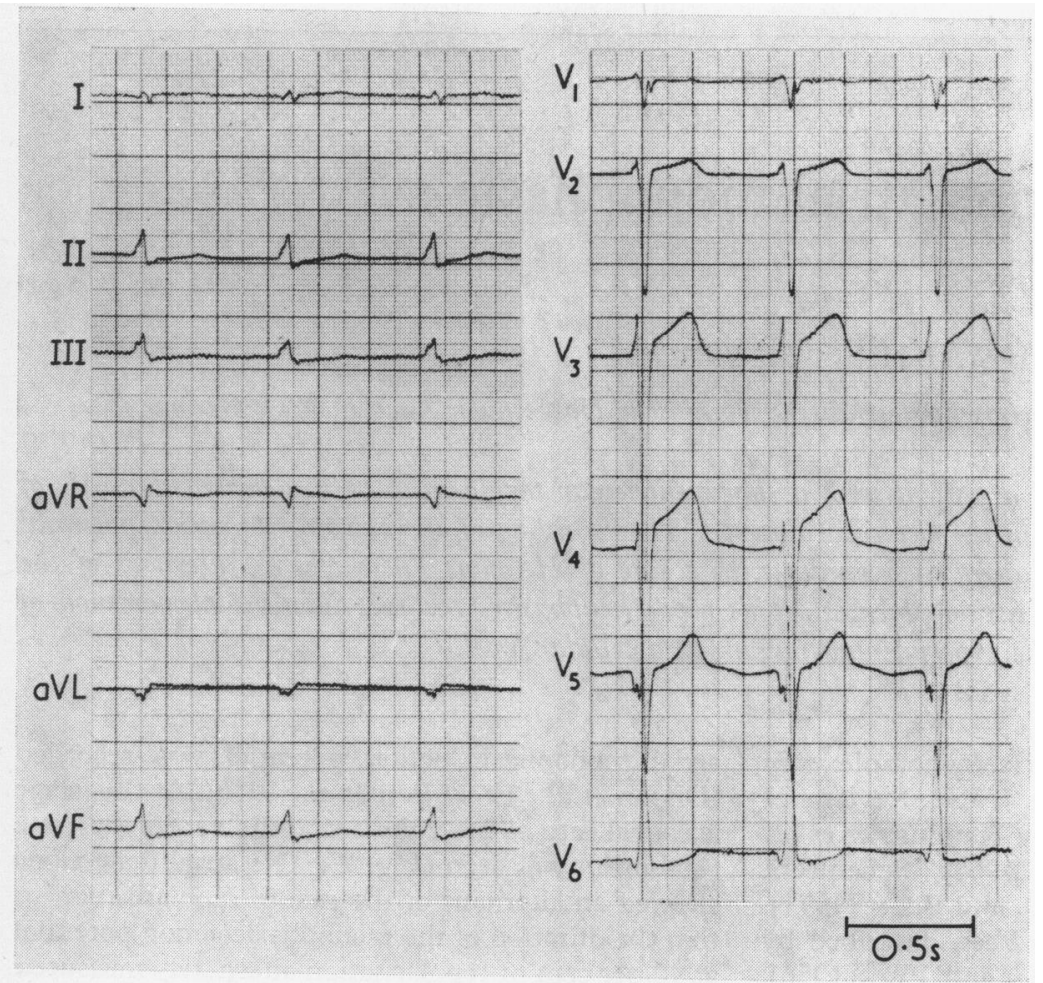

Fig. 1 Electrocardiogram at admission $(50 \mathrm{~mm} / \mathrm{s})$. No visible $P$ waves. Regular ventricular rhythm with a rate of $109 / \mathrm{min}$.

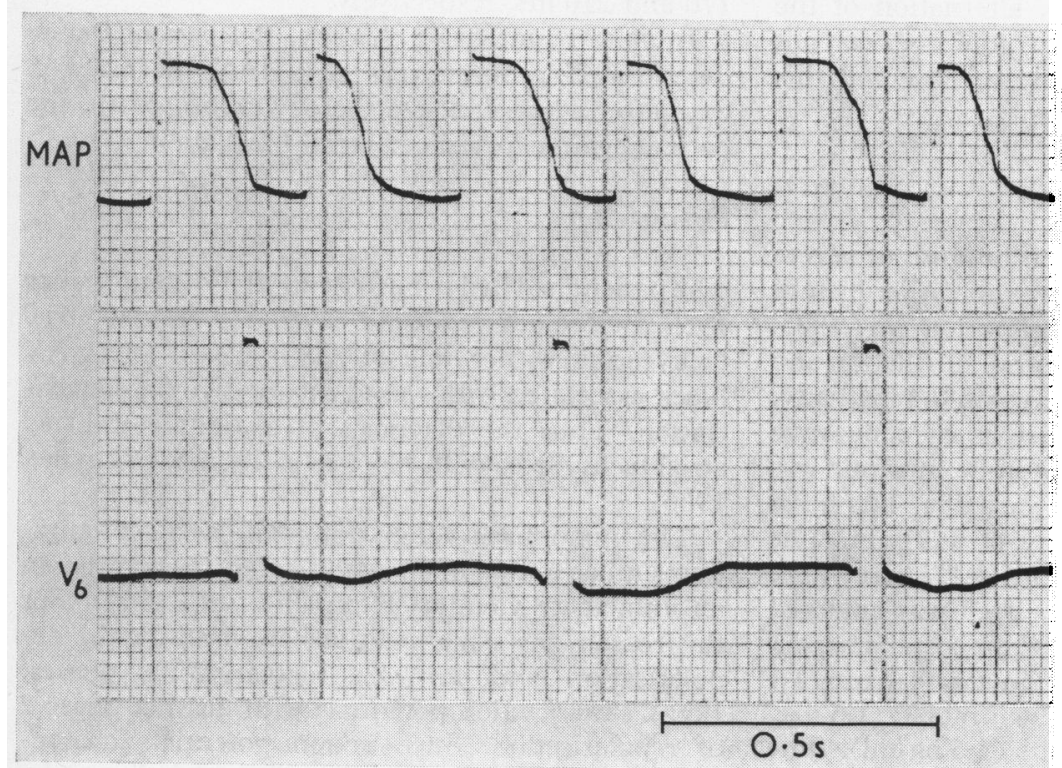

Fig. 2 Top: monophasic action potential of the right atrium (MAP). Bottom : lead V6 recorded with threefold amplification. Alternans of phase 2 of repolarisation in the $M A P$.

of cells from which the monophasic action potential was made do not represent the true pacemaker because the recording is devoid of slow diastolic depolarisation.

The first electrical alternans in the monophasic action potential in the experimental animal was described by Schütz as early as 1936 . Using the technique for recording intracellular action potential (Ling and Gerard, 1949), the phenomenon of alternation was first described by Hoffman and 
Suckling in 1954. By means of tri-iodothyronine, thyroxine, and acute anoxia, Kleinfeld et al. (1956) were able to reproduce, in single ventricular fibres of the frog heart, four types of electrical alternans; namely alternation in: (1) the rate of depolarisation, (2) the rate of repolarisation, (3) the magnitude of the action potential, and (4) hyperpolarisation.

In our case, there was an alternation of the rate of repolarisation; more precisely of phase 2 of repolarisation. As an explanation of the alternans observed in our patient, we propose the following hypothesis. During phase 2 of repolarisation, calcium and sodium ions flow across the membrane through the slow channel (Reuter, 1975; Zipes, 1976). The activation of this channel is not only voltage, but also time, dependent (Kohlhardt, 1975; Zipes, 1976). In our patient, during atrial tachycardia, the slow channel is fully opened only every second beat because of the fast rate. In this manner the phenomenon of alternans is to be seen as $2 / 1$ alternation in the degree of opening of the slow channel.

The alternans of the monophasic action potential has not yet been seen in patients with atrial flutter, an arrhythmia with a higher rate than the atrial tachycardia (Olsson, 1971; Gavrilescu et al., 1973). We assume, therefore, that in our case the alternans is not a physiological rate-dependent phenomenon, but merely the result of a disorder in the atrial cell membrane.

Three days after the recording of the monophasic action potential, the patient died. Whether the alternans of the atrial monophasic action potential is a sign of poor prognosis remains to be clarified by further investigations.

\section{References}

Bellet, S. (1971). Clinical Disorders of the Heart Beat, 3rd ed., p. 611. Lea and Febiger, Philadelphia.

Bernreiter, M. (1956). Unusual electrocardiographic findings in cardiac amyloidosis. Fournal of the American Medical Association, 161, 441.

Chung, K. Y., Walsh, T. J., and Massie, E. (1964). Electrical alternans; a report of 12 cases. American fournal of the Medical Sciences, 248, 212-220.

Colvin, J. (1958). Electrical alternans: case report and comments on the literature. American Heart fournal, 55, 513-517.

Gavrilescu, S., Cotoi, S., and Pop, T. (1973). Monophasic action potential of the right atrium in paroxysmal atrial flutter and fibrillation. British Heart fournal, 35, 585-589.

Hamburger, W. W., Katz, L. N., and Saphir, O. (1935). Electrical alternans-a clinical study with a report of two necropsied cases. Transactions of the Association of American Physicians, 50, 310-334.

Hoffman, B. F., and Cranefield, P. F. (1960). Electrophysiology of the Heart, p. 42. McGraw-Hill, New York.

Hoffman, B. F., Cranefield, P. F., Lepeschkin, E., Surawicz, B., and Herrlich, H. C. (1959). Comparison of cardiac monophasic action potentials recorded by intracellular and suction electrodes. American Fournal of Physiology, 196, 1297-1301.

Hoffman, B. F., and Singer, D. H. (1964). Effects of digitalis on electrical activity of cardiac fibers. Progress in Cardiovascular Diseases, 7, 226-260.

Hoffman, B. F., and Suckling, E. E. (1954). Effect of heart rate on cardiac membrane potentials and the unipolar electrogram. American fournal of Physiology, 179, 123-130.

Hogan, P. M., and Davis, L. D. (1968). Evidence for specialized fibers in the canine right atrium. Circulation Research, 23, 387-396.

Kisch, B. (1949). Auricular alternation after propyl-thiouracil. Experimental Medicine and Surgery, 7, 173-176.

Kleinfeld, M., Stein, E., and Magin, J. (1956). Electrical alternans in single ventricular fibers of the frog heart. American fournal of Physiology, 187, 139-142.

Kohlhardt, M. (1975). Transmembranäre Einwärtsströme bei der Erregung des Herzens. Klinische Wochenschrift, 53, 1089-1099.

Levine, H. D. (1966). The clinical diagnosis of PAT with block. In Mechanisms and Therapy of Cardiac Arrhythmias, p. 117. Ed. by L. S. Dreifus, W. Likoff, and J. H. Moyer. Grune and Stratton, New York and London.

Lewis, T. (1910). Notes upon alternation of the heart. Quarterly fournal of Medicine, 4, 141-144.

Ling, G., and Gerard, R. W. (1949). The normal membrane potential of frog sartorius fibers. Fournal of Cellular and Comparative Physiology, 34, 383-396.

Olsson, S. B. (1971). Monophasic action potentials from right atrial muscle recorded during heart catheterization. Acta medica Scandinavica, 190, 369-379.

Olsson, S. B., Varnauskas, E., and Korsgren, M. (1971). Further improved method for measuring monophasic action potentials of the intact human heart. Fournal of Electrocardiology, 4, 19-23.

Piso, H. J. (1956). Elektrische alternans bij aandoeningen van het pericardium. Nederlandsch Tijdschrift voor Geneeskunde, 100, 3874-3880.

Pop, T., Fleischmann, D., and Effert, S. (1976). The recording of the human right atrial monophasic action potential. In Cardiac Pacing, p. 80. Ed. by B. Lüderitz. Springer Verlag, Heidelberg.

Reuter, H. (1975). Inward calcium current and activation of contraction in mammalian myocardial fibers. In Basic Functions of Cations in Myocardial Activity, p. 13. Ed. by A. Fleckenstein and N. S. Dhalla. University Park Press, Baltimore.

Schamroth, L., Segal, F., and Rabinowitz, D. (1959). Electrical alternans with unusual features. American Heart fournals, 58, 900-904.

Schütz, E. (1936). Elektrophysiologie des Herzens bei einphasischer Ableitung. Ergebnisse der Physiologie, biologischen Chemie und experimentellen Pharmakologie, 38, 493620.

Spang, K. (1957). Rhythmusstörungen des Herzens. Systematik, Ursache und klinische Bedeutung, Therapie, p. 160. G. Thieme Verlag, Stuttgart.

Zipes, D. P. (1976). Recent observations supporting the role of slow current in cardiac electrophysiology. In The Conduction System of the Heart. Structure, Function and Clinical Implications, p. 85 . Ed. by H. J. J. Wellens, K. Lie, and M. J. Janse. H. E. Stenfert Kroese B.V., Leiden.

Requests for reprints to Dr. T. Pop, Abteilung Innere Medizin I, Rheinisch-Westfälische Technische Hochschule, Goethestrasse 27/29, 51 Aachen, West Germany. 